\title{
Voice prosthesis rehabilitation after total laryngectomy: are satisfaction and quality of life maintained over time?
}

\author{
Riabilitazione vocale mediante protesi fonatoria dopo laringectomia totale: \\ soddisfazione e qualità di vita sono mantenute nel tempo?
}

\author{
A. GALLI, L. GIORDANO, M. BIAFORA, M. TULLI, D. DI SANTO, M. BUSSI \\ Department of Otorhinolaryngology, San Raffaele Scientific Institute, Milan, Italy
}

\begin{abstract}
SUMMARY
Total laryngectomy is the standard of care for advanced laryngeal/hypopharyngeal cancer. Effective voice rehabilitation is mandatory and tracheo-oesophageal speech (TES) has progressively gained approval. In 2011, we evaluated quality of life (QoL) and satisfaction after TES rehabilitation, demonstrating its efficacy in highly motivated subjects. The aim of the present study was to investigate whether those results are maintained over time within the same selected cohort. 15 of 24 patients were left with a minimum 12 year-follow up after voice prosthesis (VP) implantation. Short Form 36-Item Health Survey (SF-36) for QoL assessment and a study-specific structured questionnaire for evaluation of TES-related satisfaction were employed. The 9/24 patients who dropped out from the follow-up were excluded from the original count and the former results were recalculated. A control group of subjects with minor ENT diseases was used for SF-36 analysis. Many SF-36 items (RP, BP, SF, RE) significantly improved over time, approaching the results of the control group. VP duration also increased (6.3 \pm 3.1 against $3.0 \pm 1.8$ months). TES-related satisfaction items did not change in a statistically significant way. Three patients $(20.0 \%)$ would not have chosen the same kind of voice restoration: these subjects are those more distant from our institution $(230 \mathrm{~km}$ and $462 \mathrm{~km}$, respectively, against a mean distance of $15.4 \pm 13.8 \mathrm{~km}$ for other patients). With the present work, we highlight how the striking results of TES can not only be maintained over time (i.e. TES-related satisfaction), but also substantially improve (i.e. QoL). An integrated, widespread network of centres for VP management is needed to optimise patient follow-up and allow studies on larger series.
\end{abstract}

KEY WORDS: Total laryngectomy • Voice prosthesis • Voice rehabilitation • Tracheo-oesophageal speech

\section{RIASSUNTO}

La laringectomia totale è ancora oggi gold standard terapeutico per molti carcinomi ipofaringo-laringei in stadio avanzato. Una corretta riabilitazione vocale postoperatoria è indispensabile e la voce tracheo-esofagea (VTE) ha progressivamente raccolto consensi crescenti in quest'ambito. Abbiamo in precedenza (2011) valutato la qualità di vita (QoL) e la soddisfazione riguardante la riabilitazione mediante VTE, dimostrando la sua efficacia in soggetti altamente motivati. Scopo del presente lavoro è di indagare se tali risultati siano mantenuti nel tempo all'interno della medesima coorte di pazienti. Dei 24 soggetti originari solo 15 rimangono ad oggi intervistabili, con un follow-up minimo di almeno 12 anni dopo il posizionamento della protesi fonatoria (PF). La QoL è stata indagata mediante Short Form 36 (SF-36) mentre la soddisfazione associata alla riabilitazione con VTE attraverso un questionario specifico ad essa dedicato. I risultati concernenti i 9 pazienti usciti dalla coorte originaria sono stati esclusi dal computo iniziale e lo stesso ricalcolato per evitare "selection bias". Per quel che concerne l'analisi con SF-36, è stato utilizzato un gruppo di controllo costituito da soggetti afferenti al nostro istituto per problematiche ORL minori. Molti item della valutazione SF-36 (RP, BP, SF, RE) sono incrementati significativamente nel tempo, approssimandosi ai risultati del gruppo di controllo. Anche la durata media delle singole PF è cresciuta negli anni $(6,3 \pm 3,1$ mesi contro 3,0 $\pm 1,8)$. Al contrario gli item associati all'analisi della soddisfazione correlata alla riabilitazione mediante VTE non si sono modificati in misura statisticamente significativa. Tre pazienti (20,0\%), inoltre, non sceglierebbero di nuovo tale tipologia di riabilitazione vocale: questi soggetti sono anche i più distanti dal nostro ospedale (230 e $462 \mathrm{~km}$, contro una distanza media di 15,4 $\pm 13,8 \mathrm{~km}$ negli altri pazienti). Il presente lavoro rileva come i risultati positivi della riabilitazione vocale mediante VTE possano non solo mantenersi nel tempo (i.e. soddisfazione), ma anche migliorare sensibilmente (i.e. QoL). Si rende tuttavia necessaria la creazione di un network integrato di centri deputati alla gestione delle PF per ottimizzare il follow-up dei pazienti e consentire valutazioni cliniche su più larga scala. 


\section{Introduction}

Laryngeal carcinoma accounts for about 130,000 new cases per year worldwide with 80,000 deaths annually ${ }^{1}$. Hypopharyngeal carcinoma with laryngeal extension is generally less frequent, although its prognosis is usually worse ${ }^{2}$. When diagnosed at an early stage, the disease is amenable for organ-preservation surgery or radiation therapy alone, with excellent oncological outcomes and good functional results ${ }^{3}$. However, in more advanced stages, especially in case of invasion of the laryngeal cartilaginous framework, total laryngectomy (TL) remains essential to achieve satisfying loco-regional control. Concurrent chemo-radiotherapy (CRT) may still represent a valid alternative in patients whose local and general conditions allow this approach ${ }^{4}$. Whatever organ-preservation protocol is adopted firstly, TL can be taken into account as salvage treatment in case of local persistence/failure ${ }^{5}$.

Despite ensuring good oncological outcome in many locoregionally advanced cases, TL is associated with substantial physical and psychological sequelae, affecting basic life functions such as breathing, swallowing and oral communication. Permanent tracheostomy and loss of natural voice worsen patients' quality of life (QoL), resulting in social stigma and consequent psychological discomfort ${ }^{6}$. Even dysphagia, changes in taste and smell, neck or shoulder dysfunctions can play a role in increasing postoperative disability ${ }^{6}$.

Although speech alteration is not the only factor reducing patients' QoL after TL, it is usually perceived as a major contributor: significant issues in dealing with strangers and also relatives are reported ${ }^{7}$. Therefore, rapid and effective voice rehabilitation becomes crucial to help patients coping with their new condition. To date, available solutions are oesophageal speech (ES), electro-larynx (EL) and tracheo-oesophageal speech (TES) ${ }^{8}$. The latter can be performed at the same time of TL (primary tracheo-oesophageal puncture - TEP) or as a second-stage procedure (delayed or secondary TEP). There are no substantial differences in voice rehabilitation efficacy between these two approaches ${ }^{910}$. Furthermore, primary TEP does not seem to increase peri-procedural complication rates ${ }^{11}$, even in the setting of a salvage TL with vascularised free-tissue reconstruction ${ }^{12}$ : thus, it is nowadays considered as first choice, whenever feasible ${ }^{13}$. Secondary TEP may be preferred when extensive pharyngeal resections are required, since the risk of fistula formation is very high in these settings ${ }^{14}$, or to test the patients' real commitment to TES ${ }^{15}$. Regardless of when TEP is performed, TES has gradually become the gold standard for voice restoration after TL over ES and EL 131617.

We have previously performed a study assessing QoL and degree of satisfaction in TL patients after VP rehabilitation, demonstrating its good efficacy in highly motivated subjects ${ }^{18}$. The aim of the present work is to investigate whether this satisfaction is maintained over time within the same selected cohort, evaluating the long-term effects and possible pitfalls of TES.

\section{Materials and methods}

In our previous study ${ }^{18}$, we selected 42 patients who had undergone TL for hypopharyngeal or laryngeal cancer between January 2003 and January 2006. We offered them two possibilities for voice restoration: ES or TES. Twenty-four $(57.1 \%)$ chose TES and underwent implantation of Provox2 VP (Atos Medical, Hörby, Sweden). During TL a section of sternal heads of sternocleidomastoid muscles and a short anteriorly positioned cricopharyngeal muscle myotomy have always been performed, reducing the chances of deep stoma evolution (which would increase the risk of vertical slit tracheostomal stenosis and difficulty in VP management) and hypertonicity of the pharyngo-oesophageal segment (which would make voicing harder in both ES and TES). Videofluoroscopy and Taub test were also routinely realised before planning a secondary TEP procedure. The selected cohort consisted of 22 males and 2 females, aged from 46 to 72 years (mean age: $63.6 \pm 4.2$ years). As a rule, TEP was performed as a secondary procedure, generally 6 months after TL ( $6.5 \pm 1.3$ months), at the end of the patients' course of treatment: the presumed need for extensive pharyngo-laryngeal resections, frequently in salvage settings and/or post-operative irradiation play a role in the decisional algorithm. We investigated QoL and satisfaction within this cohort (group A) in comparison to TL patients trained for ES (group B) and subjects with minor ENT diseases referring to our clinic (group C; control group). QoL was assessed through Short Form 36-Item Health Survey (SF-36); satisfaction of TES patients was evaluated with a study-specific structured questionnaire. Both questionnaires were administered one year after TEP procedure during regular, ENT follow-up visits. With the present work we reconsidered QoL and TES-related degree of satisfaction within the same cohort of patients, wondering whether those early, positive results were maintained over time. Of the original group A (24 subjects), 2 patients died of progressive disease $(8.4 \%, 2 / 24)$, and 4 of unrelated causes $(16.8 \%, 4 / 24)$. Three patients were lost to follow-up $(12.5 \%, 3 / 24)$. All the remaining $15 / 24$ patients had at least a 12-year follow-up period after VP implantation (range: 12-15 years). Patient characteristics are summarised in Table I. A survey was conducted using the same questionnaires. To obtain comparable results and avoid selection bias, the 9/24 patients who dropped out from the follow-up were 
excluded from the original count and the former results recalculated. Likewise, in our previous work, a control group of subjects with minor ENT diseases referring to our facility (homogeneous by demographics characteristics to the present study cohort) was employed for SF-36 analysis.

All procedures were in accordance with the ethical standards of the institutional and/or national research committee and with the principles stated in the Declaration of Helsinki "Ethical Principles for Medical Research Involving 'Human Subjects", adopted by the 18th World Medical Assembly, Helsinki, Finland, June 1964, and as amended most recently by the 64th World Medical Assembly, Fortaleza, Brazil, October 2013.

Statistical analysis was performed with SPSS statistical package (IBM Corp., version 20). Satisfaction of TES voice rehabilitation was compared with 2011 results through Fisher's exact test, when feasible. Paired samples Student's t-test was used to assess variation of QoL through the years. A $\mathrm{p}<0.05$ was considered significant.

\section{Results}

\section{QoL assessment}

Results of the SF-36 survey are shown in Table II, comprehensive of outcomes control group. We found a substantial in-

Table I. Patient characteristics.

\begin{tabular}{lcc}
\hline Demographics & Age at surgery & $65.2 \pm 9.8$ years \\
& Age at follow-up & $76.2 \pm 9.1$ years \\
& Gender & Male: $13 / 15(86.7 \%)$ \\
& Female: $2 / 15(13.3 \%)$ \\
& Heavy smokers (> 10 PY) & $14 / 15(93.3 \%)$ \\
T site & Larynx & $6.2 \pm 2.1$ months \\
& Hypopharynx & $12 / 15(80.0 \%)$ \\
Tumour stage & Thyroid & $2 / 15(13.3 \%)$ \\
& III & $1 / 15(6.7 \%)$ \\
Surgery & IV & $2 / 15(13.3 \%)$ \\
& Laryngectomy & $13 / 15(86.7 \%)$ \\
Neck dissection & Pharyngo-laryngectomy & $10 / 15(66.7 \%)$ \\
Timing of surgery & Bilateral & $15 / 15(33.3 \%)$ \\
& Primary & $7 / 15(100.0 \%)$ \\
Radiotherapy & Salvage & $8 / 15(53.7 \%)$ \\
& Primary treatment & $8 / 15(53.3 \%)$ \\
& Adjuvant & $7 / 15(46.7 \%)$ \\
Concomitant & Overall & $15 / 15(100.0 \%)$ \\
chemotherapy & Yes (CDDP) & $13 / 15(86.7 \%)$ \\
Pharyngeal mucosa & No & $2 / 15(13.3 \%)$ \\
reconstruction & Primary closure & $10 / 15(66.7 \%)$ \\
& Pedicle PMMF & $2 / 15(13.3 \%)$ \\
PY: & RFFF & $3 / 15(20.0 \%)$ \\
\hline
\end{tabular}

PY: pack/year; VP: voice prosthesis: CDDP: cisplatin: PMMF: pectoralis major myocutaneous flap; SCAIF: supraclavicular artery island flap; *: pedicle/free flap harvested for interposing purposes are excluded from the count. crease in terms of QoL in role physical $(\mathrm{RP})$ area $(\mathrm{p}<0.001)$, bodily pain (BP) area $(\mathrm{p}<0.001)$, social functioning (SF) area $(\mathrm{p}<0.001)$ and role emotional $(\mathrm{RE})$ area $(\mathrm{p}=0.03)$ in comparison with the 2011 results ${ }^{18}$. Also, other sections demonstrated a trend towards a better-perceived long-term QoL, although not in a statistically significant manner. The present QoL outcomes, in particular, approached the results of the control group, without statistically significant differences, except for the bodily pain (BP) area in which TES patients achieved even better scores $(\mathrm{p}<0.001)$.

\section{TES-related satisfaction survey}

Long-term degree of satisfaction was assessed through a study-specific structured questionnaire (Table III), the same survey we used in our previous analysis ${ }^{18}$. The answers were grouped two by two to allow statistical comparison using Fisher's exact test, when feasible. Voice clarity, loudness, tone, fluency and clarity on the telephone seemed to improve slightly over time, with a higher percentage of patients perceiving those parameters as "good" or "reasonable". However, this subtle difference was not statistically significant. Also, voice-related QoL seemed to ameliorate over the years, with $86.7 \%$ of patients (13/15) reporting an improvement with TES $(73.3 \%$ in $2011,11 / 15)$, while overall satisfaction behaved in the opposite way, with $93.3 \%$ of patients "satisfied" or "very satisfied" in 2011 vs $80.0 \%$ at present. Nevertheless, neither of these differences reached statistical significance.

VP replacement occurred more frequently in 2011 (every $3.0 \pm 1.8$ months) than at present $(6.3 \pm 3.1$ months $)$. Leakage through VP (i.e. trans-prosthetic leakage) and/ or impaired voicing, both caused by loss of one-way valve function as a consequence of fungal-bacterial colonisation, followed by leakage around VP (i.e. peri-prosthetic leakage) were the main reasons for valve replacement both previously and currently (Table III). This latter condition is indeed a troublesome issue to cope with, since VP substitution is frequently not sufficient to resolve it. In our case, we added a peri-prosthetic, tailored silastic collar to cover the defect on the tracheal side. Daily cleaning routine was not substantially modified over the years ( 2.5 times per day in our previous analysis, 2.0 in the present one).

The capacity to be understood by relatives or strangers, even on the telephone, was essentially preserved over time, with no significant differences (Table III). However, an increased difficulty in noisy environments was noted. Two patients $(13.3 \%, 2 / 15)$ reported to have sometimes considered removing the VP, as in our previous analysis. Interestingly, $20.0 \%$ of our cohort (3/15) would not choose the same kind of voice restoration (i.e. TES) if they could turn back time. None of the patients reported the same will in 2011. Sub- 
Table II. Short Form 36-Item Health Survey (SF-36) analysing quality of life (QoL) in total laryngectomy patients one year after voice prosthesis implantation ${ }^{18}$ and over time (11 years or more after trachea-oesophageal puncture) and in the control group. Paired samples Student's t-test was used in order to assess variation of perceived QoL.

\begin{tabular}{lccc} 
& $\mathbf{2 0 1 1}{ }^{18}$ & $\mathbf{2 0 1 7}$ & Control group \\
PF & $73.2 \pm 27.5$ & $82.3 \pm 20.0$ & $89.3 \pm 10.1$ \\
RP & $50.1 \pm 30.7$ & $83.3 \pm 32.3$ & $85.7 \pm 9.5$ \\
BP & $73.1 \pm 14.1$ & $94.8 \pm 13.8$ & $80.3 \pm 12.5$ \\
GH & $58.7 \pm 16.3$ & $63.0 \pm 20.2$ & $66.3 \pm 14.2$ \\
VT & $67.8 \pm 13.6$ & $69.3 \pm 17.5$ & $71.3 \pm 13.7$ \\
SF & $72.1 \pm 12.7$ & $88.3 \pm 16.7$ & $90.7 \pm 7.6$ \\
RE & $69.4 \pm 24.0$ & $84.5 \pm 30.5$ & $85.7 \pm 18.5$ \\
MH & $69.9 \pm 15.3$ & $71.5 \pm 21.2$ & $71.9 \pm 11.5$ \\
\hline PF:Physca
\end{tabular}

PF: physical functioning area, concerning limitations to everyday activities; RP: role physical area, evaluating the influence of physical limitations on activities or work; BP: bodily pain, related to pain and its influence on everyday life; GH: general health, estimating the actual health status and self-expectation about future health development: VT: vitality, related to the feeling of being full of energy or exhausted; SF: social functioning, related to the influence of physical or mental limitations on social activities; RE: role emotional, evaluating the influence of emotional problems on activities or work; MH: mental health, concerning general mental health including depression, anxiety and mood; NSS: not statistically significant.

jects who referred these two issues are those more distant from our facility $(230 \mathrm{~km}$ and $462 \mathrm{~km}$, respectively, against a mean distance of $15.4 \pm 13.8 \mathrm{~km}$ for the other patients).

\section{Discussion}

TL remains the standard of care for advanced laryngeal/ hypopharyngeal carcinoma, either as primary procedure or as salvage treatment after failure of chemo-radiation protocols ${ }^{45}$. Despite its straightforward oncological efficacy, TL results in dramatic physical and functional changes: permanent tracheostomy and loss of natural voice are especially perceived as the major contributors ${ }^{6}$. Rapid, effective voice rehabilitation is essential ${ }^{78}$.

Since its introduction as a viable approach for voice restoration after TL, TES has gradually become the gold standard ${ }^{13} 1617$. The achieved vocal quality is generally superior to ES and EL from both objective and subjective points of view ${ }^{16}$ and acoustically more comparable to normal laryngeal speech ${ }^{19}$. Our initial policy was to perform almost exclusively secondary TEP, since we deal generally with extremely advanced diseases, often as CRT failure, often requiring extensive pharyngo-laryngeal resections and/or adjuvant therapies: this is why our former cohort includes only "secondary" patients ${ }^{12}$. This also allowed us to verify patients' adaptability to ES and eventual commitment to TES, since many subjects preferred not to undergo another surgical operation and, mostly, to develop a kind of hospitaladdiction for VP replacement ${ }^{15}$. Nowadays our attitude has greatly changed toward a primary TEP philosophy, accord- ing to well-known evidence underplaying the role of adjuvant radiation in increasing the risk of perioperative complications ${ }^{20}$. The worse prognosis associated with salvage $\mathrm{TL}^{21}$ could also favour a primary TEP approach, offering patients a better residual QoL.

Our previous study helped to emphasise the positive effects of TES rehabilitation on QoL of TL patients ${ }^{18}$. In comparison with ES, we found that TES helped to improve patients' self confidence and limit postoperative social disability ${ }^{18}$. With this evidence in mind, we tried reassessing QoL and degree of satisfaction many years after TEP procedure, wondering whether those positive results were maintained over time.

Despite the small size of our cohort, we interestingly found that QoL outcomes were better today (12 years or more after VP implantation) than at one year after TEP (Table II), despite the natural aging of the sample. Through the SF-36 survey, we detected a significant improvement in role physical (RP), bodily pain (BP), social functioning (SF) and role emotional (RE) areas and a trend towards a better-perceived long-term QoL in other sections in comparison with the 2011 results ${ }^{18}$. These striking evidences could be explained by many reasons, not necessarily related to TES itself, and firstly the progressive healing of surgical sequelae and CRT side effects and decreasing chances of disease relapse ${ }^{22}$. It is well known that head and neck cancer patients taking QoL surveys more than 12 months after diagnosis and treatment report better outcomes in many domains ${ }^{23}$. Moreover, patients tend to be accustomed to their laryngectomee-condition, demanding for greater social integration ${ }^{22}$ : the similarity of SF-36 outcomes between the present results and the control group (Table II) can indeed support these interpretations.

If QoL seemed to improve, long-term degree of satisfaction of TES as source of voice restoration remained approximately stable over time (Table III). Although roughly increased, the results in term of voice clarity ("good" or "reasonable" for $73.3 \%$ of patients against $60.0 \%$ in 2011), voice loudness (66.7\% vs $60.0 \%)$, tone ( $66.7 \%$ vs $60.0 \%$ ), fluency $(73.3 \%$ vs $60.0 \%)$ and clarity on the telephone ( $60.0 \%$ vs $53.3 \%)$ did not achieve significant differences. Also, the specific, positive effect of TES voice restoration on QoL seemed to increase in comparison to our previous analysis (86.7\% of patients perceived their QoL as "a lot" or "quite a bit" improved by TES against $73.3 \%$ in 2011); in the same way, overall satisfaction with TES seemed to worsen $(93.3 \%$ of patients "satisfied" or " very satisfied" in 2011, $80.0 \%$ today): however, neither of these two changes reached statistical significance. The increased difficulty in noisy environments reported by a few patients (13.3\%) could be considered as a consequence of the above-mentioned greater need for social integration. Long-term maintenance of TES-related satisfaction is actu- 
Table III. Questionnaire for assessment of the degree of satisfaction of vocal rehabilitation with tracheo-oesophageal puncture (TEP) and voice prosthesis (VP) implantation evaluated one year after TEP procedure ${ }^{18}$ and over time (11 years or more after VP insertion).

\begin{tabular}{|c|c|c|c|c|}
\hline \multirow{2}{*}{\multicolumn{5}{|c|}{ Satisfaction }} \\
\hline & & & & \\
\hline $\begin{array}{l}\text { Are you satisfied with your voice after the positioning } \\
\text { of the VP? }\end{array}$ & $\begin{array}{l}\text { (1) "Not satisfied" or "somewhat satisfied" } \\
\text { (2) "Satisfied" or "very satisfied" }\end{array}$ & $\begin{array}{c}1(6.7 \%) \\
14(93.3 \%)\end{array}$ & $\begin{array}{c}3(20.0 \%) \\
12(80.0 \%)\end{array}$ & NSS \\
\hline How would you rate the clarity of your voice? & $\begin{array}{l}\text { (1) "Poor" or "moderate" } \\
\text { (2) "Reasonable" or "good" }\end{array}$ & $\begin{array}{l}6(40.0 \%) \\
9(60.0 \%)\end{array}$ & $\begin{array}{c}4(26.7 \%) \\
11(73.3 \%)\end{array}$ & NSS \\
\hline How would you rate the loudness of your voice? & $\begin{array}{l}\text { (1) "Poor" or "moderate" } \\
\text { (2) "Reasonable" or "good" }\end{array}$ & $\begin{array}{l}6(40.0 \%) \\
9(60.0 \%)\end{array}$ & $\begin{array}{c}5(33.3 \%) \\
10(66.7 \%)\end{array}$ & NSS \\
\hline How would you rate the tone of your voice? & $\begin{array}{l}\text { (1) "Poor" or "moderate" } \\
\text { (2) "Reasonable" or "good" }\end{array}$ & $\begin{array}{l}6(40.0 \%) \\
9(60.0 \%)\end{array}$ & $\begin{array}{c}5(33.3 \%) \\
10(66.7 \%)\end{array}$ & NSS \\
\hline How would you rate the fluency of your voice? & $\begin{array}{l}\text { (1) "Poor" or "moderate" } \\
\text { (2) "Reasonable" or "good" }\end{array}$ & $\begin{array}{l}6(40.0 \%) \\
9(60.0 \%)\end{array}$ & $\begin{array}{c}4(26.7 \%) \\
11(73.3 \%)\end{array}$ & NSS \\
\hline $\begin{array}{l}\text { How would you rate the clarity of your voice on the } \\
\text { telephone? }\end{array}$ & $\begin{array}{l}\text { (1) "Poor" or "moderate" } \\
\text { (2) "Reasonable" or "good" }\end{array}$ & $\begin{array}{l}7(46.7 \%) \\
8(53.3 \%)\end{array}$ & $\begin{array}{l}6(40.0 \%) \\
9(60.0 \%)\end{array}$ & NSS \\
\hline Do you think the VP has improved your quality of life? & $\begin{array}{l}\text { (1) "No" or "a little" } \\
\text { (2) "Quite a bit" or "a lot" }\end{array}$ & $\begin{array}{c}4(26.7 \%) \\
11(73.3 \%)\end{array}$ & $\begin{array}{c}2(13.3 \%) \\
13(86.7 \%)\end{array}$ & NSS \\
\hline \multicolumn{5}{|c|}{ Voice prosthesis replacement } \\
\hline On an average, how often the VP has been replaced? & Every: & $3.0 \pm 1.8$ months & $6.3 \pm 3.1$ months & \\
\hline Reasons for replacement: & $\begin{array}{l}\text { (1) Leakage through prosthesis and/or } \\
\text { impaired voicing } \\
\text { (2) Leakage around prosthesis }\end{array}$ & $\begin{array}{l}13(86.7 \%) \\
2(13.3 \%)\end{array}$ & $\begin{array}{c}14(93.3 \%) \\
1(6.7 \%)\end{array}$ & NSS \\
\hline \multicolumn{5}{|c|}{ Voice prosthesis cleaning } \\
\hline Is the VP easy to clean? & $\begin{array}{l}\text { (1) Yes } \\
\text { (2) No }\end{array}$ & $15(100.0 \%)$ & $\begin{array}{c}14(93.3 \%) \\
1(6.7 \%)\end{array}$ & $N A^{*}$ \\
\hline Do you use a brush/pipette? & $\begin{array}{l}\text { (1) Yes } \\
\text { (2) No }\end{array}$ & $\begin{array}{c}15(100.0 \%) \\
/\end{array}$ & $15(100.0 \%)$ & $N A^{*}$ \\
\hline If yes, how many times per day? & & 2.5 per day & 2.0 per day $(1-5)$ & \\
\hline \multicolumn{5}{|c|}{ Understanding } \\
\hline Are you able to be understood easily by strangers? & $\begin{array}{l}\text { (1) "Always" or "frequently" } \\
\text { (2) "Rarely" or "never" }\end{array}$ & $15(100.0 \%)$ & $15(100.0 \%)$ & $N A^{*}$ \\
\hline $\begin{array}{l}\text { Are you able to be understood easily by strangers on } \\
\text { the telephone? }\end{array}$ & $\begin{array}{l}\text { (1) "Always" or "frequently" } \\
\text { (2) "Rarely" or "never" }\end{array}$ & $\begin{array}{c}14(93.3 \%) \\
1(6.7 \%)\end{array}$ & $\begin{array}{l}13(86.7 \%) \\
2(13.3 \%)\end{array}$ & NSS \\
\hline Are you able to be understood easily by relatives? & $\begin{array}{l}\text { (1) "Always" or "frequently" } \\
\text { (2) "Rarely" or "never" }\end{array}$ & $15(100.0 \%)$ & $15(100.0 \%)$ & $N A^{*}$ \\
\hline $\begin{array}{l}\text { Are you able to be understood easily by relatives on } \\
\text { the telephone? }\end{array}$ & $\begin{array}{l}\text { (1) "Always" or "frequently" } \\
\text { (2) "Rarely" or "never" }\end{array}$ & $\begin{array}{l}13(86.7 \%) \\
2(13.3 \%)\end{array}$ & $\begin{array}{l}12(80.0 \%) \\
3(20.0 \%)\end{array}$ & NSS \\
\hline $\begin{array}{l}\text { Are you able to be understood easily in noisy } \\
\text { environments? }\end{array}$ & $\begin{array}{l}\text { (1) "Always" or "frequently" } \\
\text { (2) "Rarely" or "never" }\end{array}$ & $15(100.0 \%)$ & $\begin{array}{l}13(86.7 \%) \\
2(13.3 \%)\end{array}$ & $N A^{*}$ \\
\hline Have you ever wanted to remove the VP? & $\begin{array}{l}\text { (1) Yes } \\
\text { (2) No }\end{array}$ & $\begin{array}{l}2(13.3 \%) \\
13(86.7 \%)\end{array}$ & $\begin{array}{c}2(13.3 \%) \\
13(86.7 \%)\end{array}$ & NSS \\
\hline $\begin{array}{l}\text { If you could turn back time, would you choose the } \\
\text { same kind of voice restoration? }\end{array}$ & $\begin{array}{l}\text { (1) Yes } \\
\text { (2) No }\end{array}$ & $15(100 \%)$ & $\begin{array}{l}12(80.0 \%) \\
3(20.0 \%)\end{array}$ & $N A^{*}$ \\
\hline
\end{tabular}

NA: Fisher's exact test not applicable because one of the variables is a "constant"; NSS: not statistically significant.

ally an expected result, as the natural consequence of thorough, initial patient selection. In fact, it is essential to predict patients and caregivers' long-lasting commitment to TES in order to achieve a good, durable functional outcome: for this purpose, ES trial and eventual secondary TEP may still represent a valid option, despite the present shift towards a primary TEP philosophy ${ }^{13}$.
The significant lengthening in VP duration we noticed could be related to many factors: increased expertise in valve management (both by patients and physicians), the progressive implementation of new-generation VPs (i.e. Provox Vega, Atos Medical, Hörby, Sweden) ${ }^{24}$ and the systematic introduction of long-term PPI therapy in TES patients, due to the emerging evidence that gastro-oesophageal reflux disease 
(GERD) on tracheo-oesophageal fistula integrity ${ }^{25}{ }^{26}$, especially in subjects who underwent radiation therapy ${ }^{15}$. These aspects are particularly meaningful in our selected cohort, since all patients were submitted to pre- or post-operative irradiation (Table I).

As previously stated, trans-prosthetic leakage and/or impaired voicing were the only reasons for valve replacement in most patients (93.3\% today, $86.7 \%$ in 2011). These conditions are caused by abnormal Candida spp-bacterial biofilm formation on the valve structures despite regular cleaning, causing improper VP closure and loss of one-way valve function ${ }^{27}$. The progressive introduction of new-generation VP (i.e. Provox Vega) could obviously play a role in increasing VP lifespan ${ }^{24}$, even if no special VP (e.g. Provox Activalve, Atos Medical, Hörby, Sweden) was employed ${ }^{13}$. We also generally administered an oral antifungal suspension (e.g. nystatin) as long as patients reported an increase in trans-prosthetic leakage.

Leakage around VP (13.3\% in 2011, 6.7\% today) is a fistularelated problem that we tackled by placing a peri-prosthetic, tailored silastic collar to cover the defect on the tracheal side as well as replacing VP with a shorter one. Both conservative measures and surgical ones are considered when dealing with peri-prosthetic leakage ${ }^{28}$ : we generally approach it by reducing VP size or putting in place a tracheal, periprosthetic washer at first, leaving fistula shrinkage, tissue augmentation and use of Provox Vega XtraSeal (Atos Medical, Hörby, Sweden) as further options in case of failure. We do not usually perform purse-string sutures. Systematic use of long-term PPI therapies is an essential supplement, as advocated in the literature ${ }^{25}$.

Despite all this favourable evidence, there is still one main pitfall to consider: although the proportion of subjects who has thought about removing VP remained the same through the years (13.3\% in 2011 and today), some of our patients $(3 / 15,20.0 \%)$ would not choose the same type of voice restoration (i.e. TES) if they could turn back time. That could apparently jeopardise TES efficacy in voice restoration over time. Curiously, patients who reported these two issues are almost the same and those more distant from our institution (230 km and $462 \mathrm{~km}$, respectively, against a mean distance from our clinic of $15.4 \pm 13.8 \mathrm{~km}$ for other patients). We could explain these facts as signs of intolerance towards periodical dependence for VP management from the facility where they underwent TEP and VP implantation, which is far away from their residence: this issue can affect indeed patients' overall satisfaction related to TES without impairing their QoL, which is mostly associated to the relational possibilities offered by TES than to its maintenance cost. This finding is not surprising, as people belonging to lower socio-economic classes or living in remote areas of countries cannot afford travelling to receive repeated health care ${ }^{29} 30$ : however, it is curious in a relative small country like Italy. This once more raises the need of creating an integrated, widespread network of centres for VP management and replacement, irrespective of the institution where TEP was performed. Beyond helping patients in dealing with VP management, this could also help to extend this kind of analysis to larger series and confirm the long-term efficacy of TES as the gold standard approach for voice rehabilitation after TL.

\section{Conclusions}

Since its introduction, TES has gradually become the gold standard for voice restoration after TL, replacing EL and ES. Our previous study tried to emphasise the positive effects of TES rehabilitation on QoL of TL patients. With the present work we highlight how those results can not only be maintained over time (i.e. TES-related satisfaction), but also substantially improve (i.e. QoL). However, we also show how distance of residence from a referral institution can potentially jeopardise these aspects. An integrated, widespread network of centres for VP management and replacement is needed to overcome the problem and allow studies on larger series.

\section{Conflict of interest statement}

None declared.

\section{References}

1 Ferlay J, Soerjomataram I, Ervik M, et al. GLOBOCAN 2012 v1.0, cancer incidence and mortality worldwide. IARC Cancer Base 2012;11.

2 Siegel R, Naishadham D, Jemal A. Cancer statistics, 2013. CA Cancer J Clin 2013;63:11-30.

3 American Society of Clinical Oncology, Pfister DG, Laurie SA, et al. American Society of Clinical Oncology clinical practice guideline for the use of larynx-preservation strategies in the treatment of laryngeal cancer. J Clin Oncol 2006;24:3693-704.

4 Chen AY, Fedewa S, Zhu J. Temporal trends in the treatment of early- and advanced-stage laryngeal cancer in the United States, 1985-2007. Arch Otolaryngol Head Neck Surg 2011;137:1017-24.

5 Silver CE, Beitler JJ, Shaha AR, et al. Current trends in initial management of laryngeal cancer: the declining use of open surgery. Eur Arch Otorhinolaryngol 2009;266:1333-52.

6 Relic A, Mazemda P, Arens C, et al. Investigating quality of life and coping resources after laryngectomy. Eur Arch Otorhinolaryngol 2001;258:514-7.

7 Nalbadian M, Nikolaou A, Nikolaidis V, et al. Factors influencing quality of life in laryngectomized patients. Eur Arch Otorhinolaryngol 2001;258:336-40.

8 Mendenhall WM, Morris CG, Stringer SP, et al. Voice rehabilitation after total laryngectomy and postoperative radiation therapy. J Clin Oncol 2002;20:2500-5.

9 Brown DH, Hilgers FJ, Irish JC, et al. Postlaryngectomy voice rehabilitation: state of the art at the millennium. World J Surg 2003;27:824-31. 
10 Guttman D, Mizrachi A, Hadar T, et al. Post-laryngectomy voice rehabilitation: comparison of primary and secondary tracheoesophageal puncture. Isr Med Assoc J 2013;15:497-9.

11 Cheng E, Ho M, Ganz C, et al. Outcomes of primary and secondary tracheoesophageal puncture: a 16-year retrospective analysis. Ear Nose Throat J 2006;85:4-7.

12 Sinclair CF, Rosenthal EL, McColloch NL, et al. Primary versus delayed tracheoesophageal puncture for laryngopharyngectomy with free flap reconstruction. Laryngoscope 2011;121:1436-40.

13 Lewin JS, Baumgart LM, Barrow MP, et al. Device life of the tracheoesophageal voice prosthesis revisited. JAMA Otolaryngol Head Neck Surg 2017;143:65-71.

14 Elmiyeh B, Dwivedi RC, Jallali N, et al. Surgical voice restoration after total laryngectomy: an overview. Indian $\mathrm{J}$ Cancer 2010;47:239-47.

15 Serra A, Di Mauro P, Spataro D, et al. Post-laryngectomy voice rehabilitation with voice prosthesis: 15 years experience of the ENT Clinic of University of Catania. Retrospective data analysis and literature review. Acta Otorhinolaryngol Ital 2015;35:412-9.

16 Tang CG, Sinclair CF. Voice restoration after total laryngectomy. Otolaryngol Clin North Am 2015;48:687-702.

17 Op de Coul BM, Hilgers FJ, Balm AJ, et al. A decade of postlaryngectomy vocal rehabilitation in 318 patients: a single Institution's experience with consistent application of provox indwelling voice prostheses. Arch Otolaryngol Head Neck Surg 2000;126:1320-8.

18 Giordano L, Toma S, Teggi R, et al. Satisfaction and quality of life in laryngectomees after voice prosthesis rehabilitation. Folia Phoniatr Logop 2011;63:231-6.

19 Makitie AA, Niemensivu R, Juvas A, et al. Postlaryngectomy voice restoration using a voice prosthesis: a single institution's ten-year experience. Ann Otol Rhinol Laryngol 2003;112:1007-10.

20 Stafford FW. Current indications and complications of tracheoe- sophageal puncture for voice restoration after laryngectomy. Curr Opin Otolaryngol Head Neck Surg 2003;11:89-95.

21 Putten L, Bree R, Doornaert PA, et al. Salvage surgery in post-chemoradiation laryngeal and hypopharyngeal carcinoma: outcome and review. Acta Otorhinolaryngol Ital 2015;35:162-72.

22 Terrell JE, Fisher SG, Wolf GT. Long-term quality of life after treatment of laryngeal cancer. The Veterans Affairs Laryngeal Cancer Study Group. Arch Otolaryngol Head Neck Surg 1998;124:964-71.

23 Terrell JE, Ronis DL, Fowler KE, et al. Clinical predictors of quality of life in patients with head and neck cancer. Arch Otolaryngol Head Neck Surg 2004;130:401-8.

24 Hancock KL, Lawson NR, Ward EC. Device life of the Provox Vega voice prosthesis. Eur Arch Otorhinolaryngol 2013;270:1447-53.

25 Lorenz KJ, Grieser L, Ehrhart T, et al. Role of reflux in tracheoesophageal fistula problems after laryngectomy. Ann Otol Rhinol Laryngol 2010;119:719-28.

26 Cocuzza S, Bonfiglio M, Chiaramonte R, et al. Gastroesophageal reflux disease and postlaryngectomy tracheoesophageal fistula. Eur Arch Otorhinolaryngol 2012;269:1483-8.

27 Leonhard M, Schneider-Stickler B. Voice prostheses, microbial colonization and biofilm formation. Adv Exp Med Biol 2015;830:123-36.

28 Lorenz KJ. The development and treatment of periprosthetic leakage after prosthetic voice restoration: a literature review and personal experience. Part II: conservative and surgical management. Eur Arch Otorhinolaryngol 2015;272:661-72.

29 Eadie TL, Doyle PC. Quality of life in male tracheoesophageal (TE) speakers. J Rehabil Res Dev 2005;42:115-24.

30 Attieh AY, Searl J, Shahaltough NH, et al. Voice restoration following total laryngectomy by tracheoesophageal prosthesis: effect on patients' quality of life and voice handicap in Jordan. Health Qual Life Outcomes 2008;6:26.

Received: June 13, 2018 - Accepted: July 16, 2018

How to cite this article: Galli A, Giordano L, Biafora M, et al. Voice prosthesis rehabilitation after total laryngectomy: are satisfaction and quality of life maintained over time? Acta Otorhinolaryngol Ital 2019;39:162-168. https://doi.org/10.14639/0392-100X-2227

Address for correspondence: Leone Giordano, San Raffaele Scientific Institute, Department of Otorhinolaryngology, "San Raffaele" Hospital, via Olgettina 58, 20132 Milan, Italy. Tel. +39 02 26432172, +39 02 26433530. Fax +3902 26433508. E-mail: giordano.leone@ hsr.it 